\section{Har vi full råderett over egen kropp?}

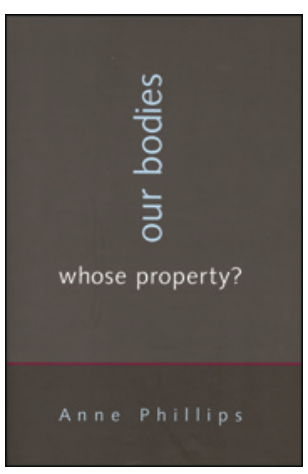

Anne Phillips

Our bodies, whose property?

202 s. Princeton, NJ: Princeton University

Press, 2014. Pris USD 28

ISBN-978-0-691-15086-4

Hva er galt med å hevde at man eier sin egen kropp, eller å gjøre kroppene våre til gjenstand for leie eller salg? Det er kjernespørsmålene fra Anne Phillips ved London School of Economics and Political Science. Hun forfølger spørsmålene ved å undersøke ulike felt som voldtekt, surrogati, prostitusjon og salg av organer og kjønnsceller. Phillips undersøker likheten og forskjellene i markedstenkningen på disse ulike områdene. Hun spør om det er mulig å ha en konsistent forståelse av kropp og å finne praktiske og gode løsninger i reguleringen av disse feltene.

Phillips er kritisk til påstander om at vi alle eier vår kropp, og at vi derfor kan gjøre hva vi vil med den. Hun viser hvordan slike påstander både er blitt brukt til å frigjøre fra undertrykkelse og til å fremme utbytting. Hun viser hvordan både tilhengerne og motstandere av ulike former for «kroppssalg» har oversolgt eierskapet til egen kropp. At kroppen er min og tilhører meg, betyr ikke nødvendigvis at jeg kan selge deler av den i et marked. På den annen side betyr ikke nødvendigvis det at penger bytter eier ved overføring av kjønnsceller eller ved surrogati, en tingliggjøring av mennesker.

Gjennom en omfattende analyse av kroppsmarkedene ønsker forfatteren å vise noen av farene ved eierskapstenkningen, som hun mener bygger på - og fremmer - vektlegging av individuelle valg. Ved dette dreies blikket bort fra de samfunnsmessige følgene. Eierskapstenkningen styrer samfunnets normer og hvilke valg folk oppfatter at de har, og kroppen oppfattes som en ressurs. Den bygger på og fremmer ulikhetene i samfunnet.

Som et alternativ mener forfatteren vi bør vende tilbake til den grunnleggende likheten som vi alle har i det at vi har en kropp og er kroppslige vesener i en felles verden. I så måte deler vi en felles sårbarhet. Fordi Phillips mener eierskaps- og markedstenkningen truer denne grunnleggende likheten mellom mennesker, og i tillegg undergraver gjensidighet og altruisme, er hun skeptisk til markeder for vev, celler og organer. Hun aksepterer likevel kompensasjon ved donasjon av kjønnsceller og surrogati, og innrømmer at det er vanskelig å sette grenser mellom kompensasjon og betaling. Hun mener at antatt samtykke bør brukes for organdonasjon for å øke tilgangen til organer.

Denne tettpakkede og litt snirklete boken henvender seg til alle som er opptatt av kroppens betydning i medisin, kjønns- og arbeidsliv. Den er viktig for alle som funderer på hvordan vi skal skaffe flest mulig organer til transplantasjon, vev til forskning og kjønnsceller for reproduksjon, og samtidig unngå at ulikhetene økes eller at fattige mennesker utnyttes. Registeret er godt, noe som gjør det lett å finne frem for den som ønsker å følge spesifikke temaer. Mitt eneste ankepunkt er at der analysen og kritikken av eierskaps- og markedstankegangen er omfattende og god, er presentasjonen av forfatterens eget ståsted skisseaktig og overfladisk.

\section{Løp og kjøp!}

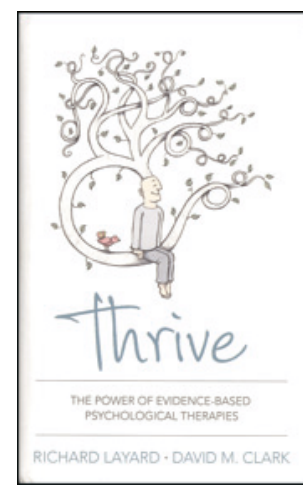

Richard Layard, David M. Clark

Thrive

The power of evidence-based psychological therapies. 384 s. London: Allen Lane, 2014 Pris GBP 20

ISBN 978-1-846-14605-3

La det være sagt med en gang, dette er et verk som bør leses. Den er aktuell for brukere, pårørende, helsepersonell flest og ikke minst for beslutningstakere innen psykisk helsevern.

Forfatterne er to av Englands ledende fagfolk innen henholdsvis $ø$ konomi og psykologi.

Utgangspunktet er misforholdet mellom forekomst og personlige og samfunnsmessige konsekvenser av psykiske lidelser på den ene siden og manglende tilgjengelighet på evidensbasert psykoterapi på den andre siden. En seksdel av voksne briter lider av depresjon eller angstlidelse, mens kun én av 10 får tilbud om samtaleterapi. Det hevdes at det $\mathrm{i}$ fremtiden vil det være en gåte hvorfor samfunnet så lenge unnlot å bygge ut behandlingstilbudet for personer med psykiske lidelser når kunnskapen om effekt av behandlingen var kjent. Det hevdes at psykologisk behandling er billig, lønnsom for samfunnet.

Første del handler bl.a. om forekomst og årsaker til psykiske lidelser, hvor mange som får behandling, og konsekvenser for den enkelte og samfunnet ved å la psykiske lidelser forbli ubehandlet. Andre del omhandler behandling og forebygging. Her er blant annet et eget kapittel som omhandler barn og ungdom.

Forfatterne beskriver bakgrunn for, og erfaringer med, implementering av et omfattende lavterskeltilbud for pasienter med psykiske lidelser - IAPT (Improving Access to Psychological Therapies). Forfatterne står selv bak prosjektet. Intet annet land i verden har satset så mye på psykologisk behandling som England. Resultatene tyder på at tilbudet er en suksess. Frem til 2013 ble totalt 380000 mennesker behandlet gjennom IAPT-programmet, og 46\% ble friske (recovery rate), og i tillegg har flere oppnådd bedring. Den psykologiske behandlingen bygger på de nasjonale retningslinjene for behandling av psykiske lidelser, de såkalte NICE-guidelines.

Det er først og fremst kognitiv atferdsterapi det handler om. Det det begrunnes med at det er den samtaleterapiformen som samlet sett har best dokumentert effekt ved psykiske lidelser.

Referanselisten er omfattende, og jeg anbefaler å bruke den aktivt. Begrensningen er at det også finnes andre psykoterapiformer enn kognitiv atferdsterapi som er effektive, men disse er i liten grad omtalt. Videre er de mer komplekse pasientene som krever mer tid, og kanskje andre metoder, lite beskrevet. Samtidig er det en styrke at det dokumenteres at ulike typer psykoterapi har forskjellig effekt på ulike indikasjoner. Det slås hull på myten om at all samtaleterapi virker tilnærmet like bra.

\section{Terje Fladvad}

Psykiater, Fladvads psykiatripraksis

Oslo 